\title{
Belarus is Going back to ... Past or Future?
}

\author{
Yakov Basin
}

\begin{abstract}
Using media information and "leaks" from those within influential circles close to the President, the author analyzes the development of the political climate in Belarus. He shows that the government is actively searchingfor ideas and ways to bring a new order to the country. According to the author, there are many ideologists who want to turn Belarus into a fascist state. The author cites examples of proliferating anti-Semitic activities, often of a criminal character, as one of the most visible signs of this political trend.
\end{abstract}

\section{Precis}

A partir d'informations venues des medias et de "fuites" issues des cercles proches du president, l' auteur analyse Ie developpement du climat politique en Belarusse. $n$ montre que Ie gouvernement recherche activement des idees et des moyens pour instaurer un ordre nouveau dans Ie pays. D' apres l' auteur il y a de nombreux ideologues qui veulent transformer Ie Belarusse en etat fasciste. L' auteur cite en guise de signes les plus visibles de cette tendance politique, l' exemple de la proliferation d' activites antisemites, souvent a caractere illegal.

\section{President Lukashenko Is Pushing to Form a Fascist Country}

The Belarus Government is actively searching for new ideas and ways to bring order to their country. Some of them directly affect the Jewish minority group. In particular, there is a lot of information telling about the possible embrace of monarchical past, revival of the Noble society, and even the forma-

Dr. Yakov Basin is Director of BelarussianAmerican, Bureau on Human Rights, Minsk, Belarus. About ten years ago he started his very active political life as one of the leaders of Jewish community in this country, and as a member of executive Council of $V A A D$, Moscow-based Jewish organization. tion of an" Aryan," fascist state. ${ }^{1}$ However, as a rule, such informa tion hardly ever appears in media, since the government plays a major role in all of these political processes.

On July 9, 1997, there was a meeting in the Institute Belinformprognosis in Minsk organized by its director O. G. Simenko, and the administration of the President of Belarus. The main theme was "The Knowledge at the Crossroads of Reforms." The discussion was concerned with creation of a new political order in Belarus. That meeting was open only to people representing the government.

The speech on "Aryan roots" of Slavic people, an order of society based on the believe in the genetic superiority oftheAryan (in this case Slavic) people political, and the perspectives of such ideology constituted the main event of the program. It was presented by B. B. Danilov, an academic of Russian Academia of Science, and Chairman of Department of Natural Science, specially invited from Moscow for that meeting. Danilov had already been in Minsk one and half years ago accompanied by some other delegate. During that time he found many people who supported his ideas there. Before the meeting started, they were selling many brochures from the series Arijskij Put' (Aryan Way).

As expected, Danilov's speech touched a Jewish theme. He claimed that:

... Jews forcefully imposed the Jewish-Christian religion. Christianity is not a Russian religion; Prince Vladimir, who was a Jew, imposed it. People say that we are fascists, but the Jews rule the world today; we just call things as they are ...

In addition, the speaker proposed the solution to the problem. According to him, there is no such thing as democracy in this world, thus the country should be ruled from the top, as it is the case in patriarchal societies. He praised Khomeinirevolution which, according to him, could be used as a blueprint to make his visions come true.

During the meeting there were only three individuals who took a stand against the speaker. In return, E. Skoblev, the Editor of Information Bulletin of Presidents Administration and a popular writer as well as ardent antiSemite, attacked them. In response to the criticism expressed by Professor B. O. Chramov, (a politician, who found the position of Danilov unacceptable in any civilized society and who used to believe that the idea of totalitarian society hadno perspective in Belarus), Skoblev said:

I am one of the allies of the president. However, your presentation is a dirty trick. I totally agree with Danilov. Our audience is ready to understand us; the dispute is not good. Our politics is held upon the following: either we accept everything that was said so far, or not. Definitely, whatever Mr. Danilov said was right. I express my greatest regards to the Professor Semenkov for inviting Mr. Danilov.

Skoblev is also known for his articles published in an anti-Semitic journal Politicheskij Sobesednik (Political Interlocutor) where he,literally, offered "to take a gun" to resolve all problems which he believed were caused by the Jewish people. In the beginningof1997, A. Lukashenko rewarded E. Skoblev with a new title of the Senior Specialist in Culture.

The participants of the meeting discussed concepts described in the Danilov's brochure Arijskij Put'. Especially an idea of gaining a power in the country, as well as forming an Aryan empire based on the ideology of the National Socialist Party, attracted attention of the participants. According to Danilov, the ruling party must have the following gradation of members: Aryan

Refuge, Vol. 17,No. 2 (April 1998) 
activists, Aryan Socialists, and "True" Aryans. Only the last group should have the rightto take part in secret meetings. G. Rusov, the Senior Editor of Lichnost (Personality), a very anti-Semitic newspaper, made the presentation.

The overall tone of the speeches as well as the ideas presented during the meeting were enough to realize in which political direction President Lukashenko was heading to.

\section{Criminal Character of Anti- Semitism}

The summer of 1997 was remembered as time of anti-Semitic crimes in Belarus. In particular, the Jewish cemetery was destroyed in the area of Prudke in Gomel (an exact date of such a barbaric act is not known). At night ofJuly 3, justbefore the holidays dedicated to the liberation of Belarus from fascism, a young Jewish boy named E. Dobromislin was brutally killed in his own apartment in Minsk. Based on publications from the Jewish newspaper Aviv,2 the young boy was tied, bitten, and cut, while the criminals drank alcohol and listened to the music. When the victim's mother came back home, she found her son lying down on the floor bleeding. His breathing stopped. After five month the case remained open. The police have arrested one of the murderers. He, indeed, refused to betray others. Before the murder took place, the victim was threatened for several months. The criminals demanded money, as well as video equipmentwhich the victim did not have. The prosecution knew the names of these criminals, but was unwilling to arrest them. In addition, an object that resembled a cross was found in the place where the murder occurred. The victim's parents suspected that the murder followed a ritual character, because absolutely nothing was missing from the apartment that day.

One more fact brings attention to which murder that took place on Zaslavsky Street in Minsk. It happened notfar from the place where somebody often knocks down the signs with names of the righteous people, and does such outrageous acts as crushing the monuments.

Another case involved Albert Labrenev, an orthopedist from Minsk, who worked in the hospital that was recently closed. Labrenev was convicted for an organized murder of his neighbour, a 62-year-old female, who was severely beaten and died later in the hospital. The woman was found at her apartment having multiple skull traumas. A. Labrenev was arrested based on the evidence provided by the victim's son. The trial verdict was to put him behind bars for five years. The court decision was based information provided by victim's relatives only, who claimed that the victim told them about the whole incident before her death. According to her, Labrenev came to the apartment escorted by two other men. These men started beating her while Labrenev was observing the whole incident. A tense relationship between Labrenev and victim's family, which kept complaining that Labrenev "flooded" her apartment on purpose, was the alleged motive of that crime. However, the expertise proved that the victim had psychiatric problems expressed in the form of mania that "the neighbour put her under the spell."

According to the testimony of neighbours, before the accident, the victim's children threatened Labrenev for a month. The threat was accompanied by anti-Semitic slanders. The aspect of antiSemitism was emphasized during the trial many times. However, Labrenev did not highlight that aspect, since he was afraid for the life of his family. His daughter was in hiding for over two years. He and his wife lived in their friend's house.

Labrenev spent one year in prison before the case was reviewed by the Supreme Court of Belarus. The nexttrial was carried out without a witness hearing and was based on psychiatric expertise. As result, the expertise showed that the victim was not able to give adequate information about the crime to her relatives, since there were some suspicions concerning her ability to speak after the beating, although she was conscious at that time. It also appeared that the death occurred as a result of a surgery because of hematoma. Eventually, the court found Labrenevnot guilty.

Right after the announcement of the verdict, the victim's son tried to attack Labrenev inside the court. Labrenev suffered arm fracture before the fight was stopped. In addition, the victim's daughter shouted: "You will decay in the prison one way or other."

In the opinion of observers the victim's son was probably connected with some sort of criminal organization. During the trial, some facts also hinted to his connections with police. It is quite possible that his mother was a victim of Mafia. Also the real criminals, the two individuals who did the beating, were not found, because after the first conviction and trial of Labrenev the case was closed. If a new verdict stays in power, the judge might have many problems, since Labrenev would be eligible for compensation of material and moral losses.

\section{Problems of Jewish Organizations with Registration}

In Belarus, it is still very hard for Jewish communities to be registered. Out of all applications, only one was successful. The Progressive Community of Judaism was not allowed to register using the address of humanistic organization Huffed Rahamim in Grodno. It had to register at the home address of one of the members of the organization. However, the situation was the opposite in Bobruisk, where the registration at home address was not allowed. Until now, the matter concerning the registration of local Jewish communities has not been resolved. No one can influence the authority of Bobruisk in making any decision about it. In a letter to B. C. Reinhold, the leader of the local Jewish community, the representative of the authority, I. Savchenko, promised to come back to the ma tter concerning the agreement on registration of the Jewish progressive community and resolve it according to law. He agreed that the absence of localization was not a good reason for denial registration of religious organizations. But nothing has changed since than. However, the delay 
could be explained by the fact that new policy regarding those matters has not been formulated yet.

\section{Nationalism and Anti-Semitism in the Media}

The nationalism in Belarus is on the rise. In the middle of 1;)ecember last year, Minsk was visited by a group of writers who expressed their support for the President Lukashenko, who was viewed by them as the one who could "save" their Slavic nation. Among the members of that delegation were $M$. Alexeev, Proskurin, V. Karpov, V. Rasputin, and A. Kasinsev. The last one is a father of contemporary antiSemitism in the country. He is also a senior editor of a journal Nash Sovremennik (Our Contemporary). Nowadays, Minsk is full of newspapers such as Slavyanskaya Gazeta (Slavic Newspaper), for example, that have anti-Semitic character. One of the articles published in this newspaper, "Kto goniayetsya za prezrakami" (Who Is Pursuing Illusions?) was a reaction to the report of Union of Councils for Soviet Jews," Anti-Semitism in theformer Soviet Union, 1995-1997." The conclusion to a long dispute, which was not supported by any valid arguments, was very symptomatic:

We can only guess if authors of this report have ever been in the Kremlin. If they could not get there to attend a celebration of Jewish holidays, as well as music concerts of famous stars having Jewish origins, they could visit a White House in order to answer the question of who rules Russia. The invasion and the platitude of strange and aggressive "culture" desecrate the Kremlin walls that are so relic for the Russian people ... The grandchildren of creditors and salesman have always had illusory dreams ... Slavic souls are just considered as a dust of civilization (as Leiba Bronstein, i.e. Trotsky, used to call it)

... Trotsky was one of the bloody dictators of Revolution. Now, likeminded reformists, who continue to steal Russian riches, and make Russia

a poor country, honour him. ${ }^{3}$

Another newspaper, Slavyanskij

Nabat (Slavic Alarm), started to publish some articles written by one of the most reactionary representative of Orthodox Church who died two years ago. His name was Johan. In one of his articles, "Bitva za Rossiyu" (A Fight for Russia), 4 he uses a text of the Protocols of the Elders of Zion to make his point. Johan's articles make a mockery of nations which believe in a constitutional order. In the above mentioned article, he openly stated, "A constitution as you know, is nothing more than a' school' of fights, quarrels, and useless agitations; in other words, this is a 'school' that makes a nation helpless." These words were written in a form of citations from Protocols. In the conclusion the author stated that enemies to the absolutism, which should be a true form of national order, were those who accepted aconstitution, and, of course, Jews were mentioned among them.

Quite recently, between September 19 and 26, 1997, the newspaper Svobodnie Novosti Plus (Free News Plus), which is of centro-right orientation but close to democrats, published the so-called sa- tirical comments of P. Lud, who stated: "One man told people, who is responsible for all troubles. Neither the writer, nor the farmer. Again we are being disturbed by the children of Moses."s

The anti-Semitic newspaper Lichnost has accused vice-president I. Pashkevich for a desire to form of "multiconfessional" state. It seems that the nationalists would like to give the same power to the Orthodox Church as in Russia. In August of 1997, an analysis of the institutional anti-Semitism in the media was sentto a vice-president I. Pashkevich by L. Levin, a president of all Jewish communities in the country. Officially no answer followed. The antiSemitic articles continued to be published, especially in Slavic newspapers of nationalistic orientation. In the middle of December last year, the new text of such analysis was prepared. According to a decision made by Jewish Council, that analysis has to be sent directly to the Supreme Court of Belarus for a review.1I

\section{Notes}

1. This was highlighted by A. Feduta, one of the former allies of President Lukashenko, in his article "Obiknovennij slavyanski faschizm" (The Ordinary Slavic Fascism), which appeared in Belarusskaya Delovaya Gazeta, nos. 63-65, 1997.

2. Aviv, no. 7, 1997.

3. "Kto goniayetsya za prezrakarni" (Who Is Pursuing Illusions?), Slavyanskaya Gazeta, no. 3, 1997.

4. Johan, "Bitva za Rossiyu" (A Fight for Russia), Slavyanskij Nabat,no. 27 (November 13-19, 1997).

5. P. Lud, Svobodnie Novosti Plus, September 19-26, 1997. o

\section{Centre for Refugee Studies On-Line}

\section{WebSite: http://www.yorku.ca/research/crs Email: refuge@yorku.ca}

